\title{
HMG-CoA Reductase Inhibitory Activity of Gnetum gnemon Seed Extract and Identification of Potential Inhibitors for Lowering Cholesterol Level
}

\author{
Kholid Abdul Hafidz ${ }^{1}$, Nuraini Puspitasari ${ }^{1}$, Azminah ${ }^{2}$, Arry Yanuar ${ }^{2}$, Yuditya Artha ${ }^{2}$, Abdul Mun'im*1 \\ 'Department of Pharmacognosy-Phytochemistry, Faculty of Pharmacy, Universitas Indonesia, Depok, 16424 West Java, INDONESIA. \\ 2Department of Biomedical Computation, Faculty of Pharmacy, Universitas Indonesia, Depok - 16424 West Java, INDONESIA.
}

\begin{abstract}
Objectives: Melinjo (Gnetum gnemon) seeds have been known to have some biological properties. One of them is ant hypercholesterolemia. The present study investigated in vitro and in silico methods to predict potential antihypercholesterolemic of the Melinjo seed extracts of through HMG-CoA reductase inhibitory activity. Methods: Melinjo seed powders were successively extracted by reflux method using five solvents with gradient polarity including: $\mathrm{n}$-hexane, dichloromethane, ethyl acetate and methanol. All extracts were evaluated in vitro using HMG-CoA Reductase assay kit, to analyze the inhibitory activity. Molecular docking of the phytochemical content of the seeds were carried out using Auto Dock Vina, and also Ligand Scout to analyses interaction between ligand and receptor. Results: Dichloromethane extract demonstrated the highest inhibitory activity against HMG-CoA reductase with $\mathrm{IC}_{50}$ value is $0.40 \mu \mathrm{g} / \mathrm{mL}$, followed by that of ethyl acetate extract. UPLC-MS analyses showed that dichloromethane extract contained trans-resveratrol, piceid, gnetin C, gnetol, isorhapontigenin, $\varepsilon$-viniferin, gnemonol $\mathrm{L}$, and gnemonol $\mathrm{M}$. Molecular docking studies demonstrated that dimer of resveratrol such as gnemonol L, gnemosida,
\end{abstract}

and $\varepsilon$-viniferin have better free binding energy than that of monomer. piceid, gnetin $\mathrm{C}$, gnemonol $\mathrm{L}$, and gnemonol $\mathrm{M}$ could be considered as HMG-CoA reductase inhibitor. Conclusion: Gnetum gnemon seed extract showed strong HMG-CoA reductase activity. Resveratrol dimer promises as a potential lead compound to design/synthesize anti-cholesterol.

Key words: Gnetum gnemon, Melinjo, HMG-CoA Reductase, Resveratrol, Stilbene, Molecular Docking.

Correspondence :

Abdul Mun'im, Departement of Pharmacognsoy-Phytochemistry, Faculty of Pharmacy, Universitas Indonesia, Depok, 16424 West Java, INDONESIA.

Phone: (021) 7270031

Email: munim@farmasi.ui.ac.id

DOI: 10.5530/jyp.2017.9.107

\section{INTRODUCTION}

Gnetum gnemon belongs to Gnetaceae family is indigenous to Southeast Asia. This plant was known as Melinjo in Indonesia. The leaves and the seeds have been consumed as foodstuff for centuries in Java Island. ${ }^{1}$ The seeds flour was reported to be rich in protein, carbohydrates and crude fiber. ${ }^{2}$ The seeds were made to be Emping (local name) by crushing the endosperms that obtained the heated seeds, and the dried drying, and deep-frying. ${ }^{3}$ Other than as a food ingredient melinjo seeds are also reported to have benefits for health. ${ }^{3}$

Kato et al reported that the seed extracts of Melinjo demonstrated DPPH radical scavenging, pancreatic lipase and $\alpha$-amylase inhibitory, and antiimmunostimulatory activities. ${ }^{4}$ The administration of the seed extracts rich in resveratrol dimers in mice significantly reduced body weight and anti-metabolic syndrome. ${ }^{5}$ Melinjo seed extract (MSE) demonstrated potent antitumor activity in a colon tumor bearing mice. ${ }^{6}$ A study in mice, showed that MSE could improve several parameters of metabolic syndrome. In a clinical study, administration MSE decreased the serum uric acid levels by inhibiting the reabsorption of uric acid in the renal tubular epithelia as well as by increasing the HDL cholesterol levels by PPAR agonistic activity with no cause of the damage to health. ${ }^{7}$ Ethyl acetate extract of the seed demonstrated strong ACE inhibitory activity, and molecular docking analysis indicated dimer of resveratrol was considered as bioactive compound. ${ }^{8}$

The Gnetaceae family is known to contain stilbenoid group including resveratrol, gnemonols A-L, gnemonosides $\mathrm{K}$, and gnetin $\mathrm{E}$. These compounds were also successfully isolated the stem and root of Gnetum gnemon L. ${ }^{9}$ While, melinjo seeds have been reported containing gnetin L, gnetin C, gnemonosides A, C, D, and resveratrol. ${ }^{4}$ This compound distributed in some species plant including Veratrum grandiflorum, Polygonum cuspidatum, Vitis vinifera and a wide variety of other food sources. ${ }^{10,11}$ Resveratrol has been believed to explain the lower incidence of myocardial incidence. ${ }^{12,13}$ Animal studies have showen that resveratrol could reduce the expression of HMG-CoA reductase mRNA. ${ }^{14}$ It has driven considerable interest towards resveratrol in Melinjo molecular activities.

Molecular docking has been use to search and design new potential drug from natural products, such as flavonoid and alkaloid. ${ }^{15,16}$ Based on the biological activity of Melinjo seeds and its stilbene component, this study presented the HMG-CoA inhibitory activity and molecular docking of the stilbene to predict in silico HMG-CoA reductase inhibitory activity.

\section{MATERIALS AND METHODS}

\section{Melinjo seeds}

Fresh Melinjo fruits were used in this study were purchased from a local market Jakarta, Indonesia. Seeds were physically separated from the hard-coat and dried. Dried seeds were then ground to a fine flour (mesh size 30) by using a blender. The powdered seed packed in air-tight polyethylene plastic jar and refrigerated at $4^{\circ} \mathrm{C}$, prior to analysis. 


\section{Preparation of extract}

Dried melinjo seed powder was successively extracted using gradient solvents: n-hexane, dichloromethane, ethyl acetate, methanol, and distilled water. Crude extract obtained after removing solvent using rotary vacuum evaporator at $50^{\circ} \mathrm{C}$ (Buchi, Switzerland). While aqueous extract directly freezes dried with freeze dryer (ScanLaf, Denmark) into white powder.

\section{HMG-CoA reductase assay}

The HMG-CoA reductase inhibitory activity was performed on the extracts according to Zhou et al with slight modification, with pravastatin as the positive control. ${ }^{17}$ Briefly, a reaction system in vitro consist of NADPH $(4 \mu \mathrm{l})$ and the substrate (HMG-CoA, $12 \mu \mathrm{l})$ was diluted with potassium phosphate buffer (100 mM, pH 7.4) containing KCl (120mM), EDTA $(1 \mathrm{mM})$ and $5 \mathrm{~m}$ DTT $(5 \mathrm{mM})$ until final volume $200 \mu \mathrm{l}$. Two $\mu \mathrm{L}$ HMGCoA reductase (Sigma-Aldrich, Louis, USA was added to the reaction mixture as initiation time (time 0 ) and was incubated at $37^{\circ} \mathrm{C}$ in the presence or absence of samples solution $(1 \mu \mathrm{l})$.

The absorbance of NADPH was determined spectrophotometrically every $20 \mathrm{sec}$ for up to 10 minutes at $340 \mathrm{~nm}$ using a SpectraMax plus 384 microplate reader, equipped with double-beam lamp and a controlled thermostatically cell holder. Softmax Pro $^{\circ}$ by Molecular Devices, LLC was used for the control the equipment and data evaluation. Therefore, the inhibitory activities were expressed as $\%$ inhibition using the following equation:

$\%$ Inhibition $=\frac{\Delta \text { Positive Blank Absorbance }-\Delta \text { Sample Absorbance }}{\Delta \text { Positive Blank Absorbance }- \text { Negative Blank Absorbance }} \times 10$

\section{Resveratrol assay}

Resveratrol assay was performed on a Shimadzu HPLC LC-20AT, with UV detector, YMC C- ${ }_{18}$ column ( $150 \times 4.6 \mathrm{~mm}$ I.D., $\left.5 \mu \mathrm{m}\right)$, and temperature column $25^{\circ} \mathrm{C}$. Water/acetonitrile $(75 / 25)$ was adjusted to $\mathrm{pH} 3.00$ as mobile phase with flow rate $1.0 \mathrm{~mL} /$ minute. ${ }^{10}$ Injection volume was set up at $20 \mu \mathrm{L}$, monitored at 306 for 15 minutes.

\section{LC-MS analysis of dichloromethane extract}

Liquid chromatographic separations were conducted on a Xevo G2 Acquity $\mathrm{UPLC}^{\mathrm{m}}$ with $\mathrm{BEH} \mathrm{C}_{18}$ column $(50 \mathrm{~mm} \times 2.1 \mathrm{~mm}$, particle size $=1.7 \mu \mathrm{m}$, Waters Corp, Milford, MA, USA). The column and autosampler tray temperature were maintained at 35 and $4{ }^{\circ} \mathrm{C}$, respectively. The mobile phase consisting of water containing $0.1 \%$ formic acid (A) and acetonitrile containing $0.1 \%$ formic acid (B) was used at a flow rate $0.3 \mathrm{ml} / \mathrm{min}$. The gradient elution was from $95 \% \mathrm{~A}$ to $0 \% \mathrm{~A}$ within $6 \mathrm{~min}$ and then held for $1 \mathrm{~min}$. From 7 to $7.5 \mathrm{~min}$, the percentage of A was increased to $95 \%$ and maintained about $1.5 \mathrm{~min}$, then reduced to the initial condition within $1 \mathrm{~min}$ and balanced for 2 mins.

The total running time was $10 \mathrm{~min}$, and the sample injection volume was set at $5 \mu \mathrm{l}$. The UPLC system was connected to the mass spectrometer through an ESI interface and was operated in the positive ion detection mode. Nitrogen used for desolvation was $500 \mathrm{~L} / \mathrm{h}$, cone gas was set at $16 \mathrm{~L} / \mathrm{h}$. The capillary voltage was set at $3 \mathrm{kV}$, source temperature $110^{\circ} \mathrm{C}$, desolvation temperature $300^{\circ} \mathrm{C}$. Data acquisition was processed with Masslynx 4.1 software.

\section{In silico experiments}

\section{Dataset and protein-inhibitor complexes}

In silico simulations were carried out using platform with core i7 processor. A dataset of stilbene from Melinjo and Pravastatin were obtained from the published literature and used for docking. Structural information was downloaded from http://www.chemspider.com/Chemical-Structure. X-ray crystal structures of HMG-CoA reductase in complex with the two inhibitors were downloaded 3-hidroxy-3-metyl-glutaric acid [MAH] and simvastatin acid from the Protein Data Bank (PDB), complex of catalytic portion of human HMG-CoA reductase (HMGR) (PDB ID: 1DQ8) ${ }^{18}$ and HMGR in complex (PDB ID: 1HW9) ${ }^{19}$ http://www.rcsb. org/pdb/

\section{Molecular docking}

AutoDock4.2 was used for molecular docking studies calculation, using a Lamarckian genetic algorithm between flexible ligand and rigid receptor, a population size of 300, a maximum of 250000 generations and 2500000 evaluations for 100 GA runs.(20)(20) The root means square deviation tolerance was set to $2.0 \AA$ for the clustering of docking results. Interaction ligand-receptor were processed using pharmacophore feature of LigandScout (Inte:Ligand, Vienna, Austria). Visualization all ligand for hydrophobicity used program UCSF Chimera 1.10.2.

\section{RESULTS}

\section{HMG-COA reductase inhibitory activity}

Table 1 showed HMG-CoA reductase inhibitory activity of the extracts. Dichloromtehane extract demonstrated the best inhibition activity with $64.78 \%$ at $100 \mathrm{ppm}$, was followed by ethyl acetate extract with inhibition activity $57.86 \%$. Further investigation, the $\mathrm{IC}_{50}$ of dichlormethane extract was $0.40 \mathrm{mg} / \mathrm{ml}$. However, HMG-CoA reductase inhibitory activity of dichloromethane extract is lower than the trans-resveratrol.

\section{Resveratrol content}

Resveratrol assay was determined by HPLC. Figure 1 shows the chromatogram of resveratrol and dichloromethane extract. Resveratrol content of each extract was presented in Table 2. Resveratrol was found in dichloromethane, methanol and ethyl acetate extracts. Dichloromethane extract contained the highest level of resveratrol, followed by methanolic extract.

\section{LC-MS analysis}

LC-MS chromatogram showed that extract contains seven prominent peaks with molecular weight 227, 262.29, 280.296, 395.361, 455.195, $537.331,617.203$, and 779.248 au (Figure 2). Some peaks suggested to originate from the stilbene contained in Melinjo seeds, such as: gnemonoside B (m/z-779.248) and gnetin C (m/z-455.195).

\section{Molecular docking}

HMG-CoA Reductase appears as a tetrameric protein complex, structure of enzyme is shown on image below (Fig 3A and 3B). Due to efficiency of time, docking procedure was conducted using dimeric structure of enzyme complex. The validation was carried to assure the accuracy and precision of the used method. HMG-CoA Reductase enzyme complex [PDB ID 1HW9] and [PDB ID 1DQ8] were downloaded from protein data bank and redocked against their original ligand. $\mathrm{MAH}$ as the original ligand of 1DQ8 gave free binding energy value $-7.19 \mathrm{kcal} / \mathrm{mol}$ and RMSD

Table 1: HMG-CoA reductase inhibitory activity of the sample

\begin{tabular}{lc}
\hline \multicolumn{1}{c}{ Sample } & Inhibition Activity (\%) \\
\hline n-Hexane extract & 22.27 \\
Dichloromethane extract & 64.78 \\
Ethyl acetate extract & 57.86 \\
Methanolic extract & 41.85 \\
Water extract & 25.64 \\
Trans-Resveratrol & 94.61 \\
\hline
\end{tabular}

${ }^{\star}$ The values are average from the triplicate experiments. Sample concentrations are 100ppm. 
Table 2: Resveratrol content in melinjo seed extracts

\begin{tabular}{cc} 
Extract & $\begin{array}{c}\text { Concentration } \\
(\mathrm{mg} / \mathrm{kg})\end{array}$ \\
\hline n-Hexane extract & - \\
Ethyl acetate extract & 686 \\
Dichloromethane extract & 8190 \\
Methanol extract & 3184 \\
Water extract & - \\
\hline
\end{tabular}

${ }^{*}$ The values are average from the triplicate experiments.

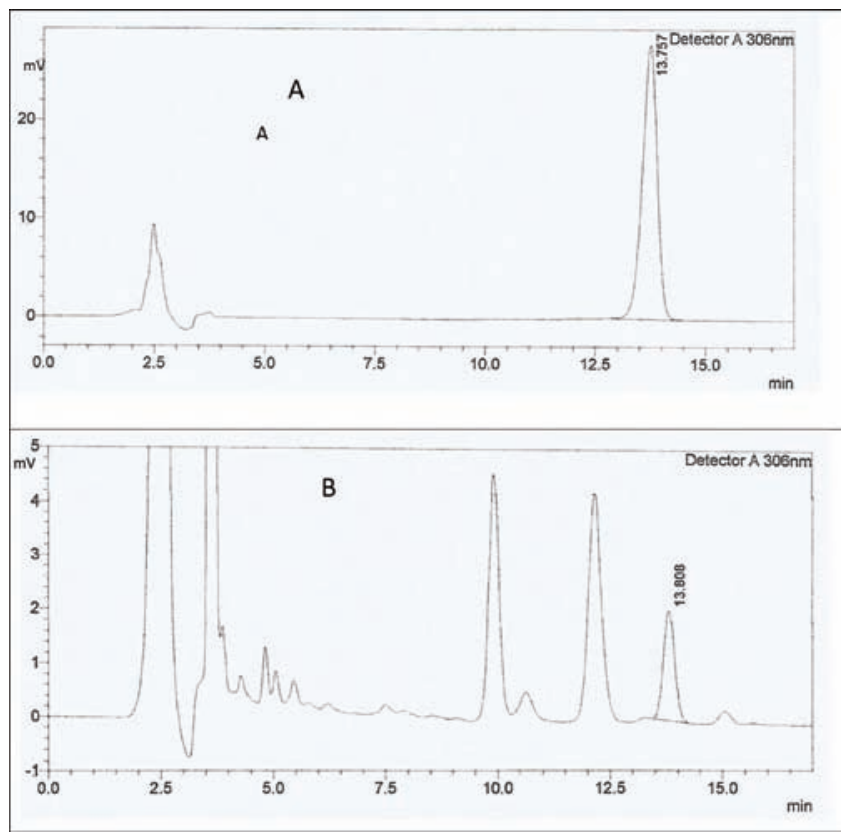

Figure 1: HPLC Chromatogram of resveratrol (A) and (B) dichlormethane extracts

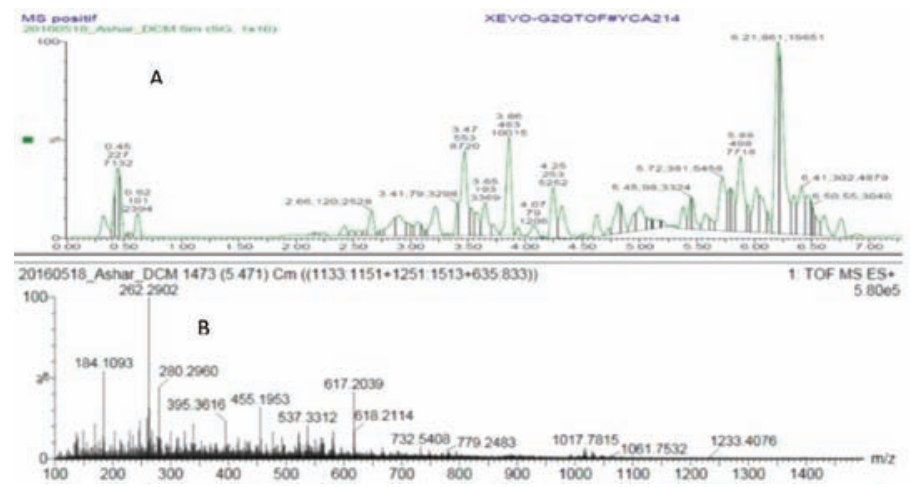

Figure 2: LC-MS/MS chromatogram of dichloromethane extract

value $1.12 \AA$. HMG-CoA Reductase complex with simvastatin gave free energy binding value as high as $-9.76 \mathrm{kcal} / \mathrm{mol}$ and RMSD as high as 1.45 Å. Obtained RMSD value of redocked MAH and simvastatin are lower than $2.00 \AA$. Therefore, the docking method is valid to dock several compounds of dichlormethane melinjo seed extract. Table 3 shows free binding energy of docked stilbenes in Melinjo seed with their ligand.

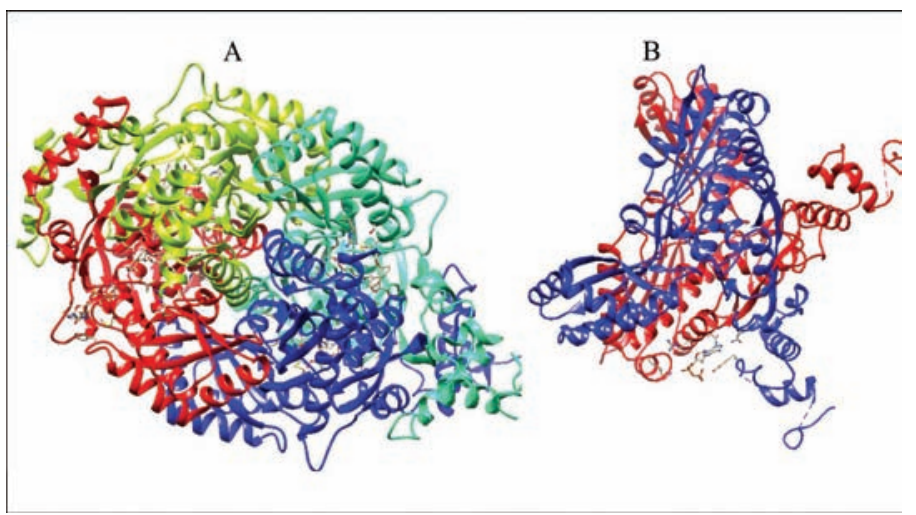

Figure 3: A) Tetrameric and B) dimeric HMG-CoA Reductase enzyme PDB ID $1 \mathrm{HW} 8$

\section{DISCUSION}

Gneteceae family was well known to be rich in stilbenoids and to be used as traditional medicine for treatment of bronchitis, arthritis, and asthma. Stilbenoids oligomers have pharmacological activity, such as: to reduce the level of sugar in the blood, show anti-inflamatory activity and induce apoptosis in colon cancer. Stilbene from Ampelopsis brevipedunculata var. hancei revealed ACE inhibitory activity in silico and in vitro. Resveratrol tetramers interact with ACE more favorably than other smaller oligomers. One member of this family is Gnetum gnemon. The fruits, leaves, and seeds are used as an ordinary vegetable in Indonesia. The occurrence of various stilbenoids was also reported in the seeds, roots and stems of the plant, however there is no information about the usage of the seeds as traditional plants. In the in silico study, dimeric resveratrol from the seeds of the plant demonstrated ACE inhibitory activity. ${ }^{8}$ The seed of Melinjo revealed strong antioxidant and tyrosinase inhibitory activity

Resveratrol as standard was quantified to obtain calibration curve and regression equation. Linearity R-value and regression equation were 0.9998 and $Y=106945 \mathrm{X}-229881$. Retention time of resveratrol observed under 306-320 nm wavelength was given a maximum peak at 7 minutes (Figure 2).

All samples were evaluated in vitro for their capability to inhibit human recombinant HMG-CoA reductase catalytic activity. The $\mathrm{IC}_{50}$ value of pravastatin as positive control was determined in preliminary test for the standardization. Calibration curve yielded a linearity with $\mathrm{R}$-value $=0.997$ and regression equation of $\mathrm{Y}=109.8 \mathrm{X}+45.909$. Obtained $\mathrm{IC}_{50}$ value of pravastatin was $87.76 \mathrm{nM}$, which was in concordance range (44.10 $70.25 \mathrm{nM}$ ) with other study. ${ }^{22,23,24}$

Sample solutions were observed in the same way of standard. Each peak in chromatogram was identified by comparing the retention time and UV spectra of the samples with that standard. Quantitation was carried out by standard external. Peak's area, then, plotted into regression equation. Resveratrol was present on three samples include ethyl acetate extract, dichloromethane, and methanol extract, with a result of 8.190, 3.184, and $686 \mathrm{mg} / \mathrm{kg}$, respectively (Table 2). Meanwhile, n-hexane and aqueous extract gave a non-significant result on HPLC separation and UV detection. The retention time of samples was similar to resveratrol after 7 minutes. UV spectra also compared with a previous study, ${ }^{10}$ which displayed a split peak, shown in Figure 1.

LC-MS chromatogram exhibited that extract contains seven prominent peaks with molecular weight 227, 262.29, 280.296, 395.361, 455.195, $537.331,617.203$, and 779.248 au. In the other hand, there are several small peaks which may have also contributed to enhance the activity. 
Cho et al. (2008) reported that resveratrol (m/z-229.0625) is responsible for its attenuation against the expression of HMG-CoA reductase mRNA in hamsters. ${ }^{14}$ Kato et al. (2009) also reported some chemical constituents from Melinjo seed extract such as gnemonoside B (m/z-779.24); gnetin $\mathrm{C}(\mathrm{m} / \mathrm{z}-455.14)$; and resveratrol $(\mathrm{m} / \mathrm{z}-229.0625)$ are responsible for antioxidant, antimicrobial, and other pharmacological properties. ${ }^{4}$ Whereas in present study distinct peaks of molecular weights $(\mathrm{m} / \mathrm{z}-227 \mathrm{au})$ was very similar to resveratrol; ( $\mathrm{m} / \mathrm{z} 779.248)$ was similar to gnemonoside $\mathrm{B}$; and (m/z-455.19) was similar to gnetin C.

The results of in vitro test demonstrated that each extract of melinjo seeds have the capability to inhibit activity of HMG-CoA reductase. Dichloromethane and ethyl acetate showed the strongest HMG-CoA reductase inhibitory activity. Dichloromethane extract demonstrated significantly inhibition activity of HMG-CoA reductase and exhibited concentration dependent manner with inhibition activity on the enzyme. Additionally, resveratrol (standard) was tested and the $\mathrm{IC}_{50}$ value was determined.

Results of docking were analyzed and the best-docked confirmation was chosen based on their number of conformations in a cluster and the lowest free energy binding. Higher numbers of conformations and the lowest binding energy indicated better affinity of the compound to be docked into HMG-CoA reductase enzyme with PDB ID 1DQ8, 1HW9.
As shown in Table 3, external compounds, piceid, gnetin C, gnemonol L, gnemonol $\mathrm{M}$, viniferin and latifolol docked better and results lower free energy binding than the original ligand $\mathrm{MAH}$ in the HMG-CoA reductase enzyme [PDB 1DQ8]. Gnetin C, gnemonoside $\mathrm{B}$, gnemonol $\mathrm{M}$ and gnemonol L, docked better than the ligand SIM4 (simvastatin) with PDB 1HW9 and ligand pravastatin as reference drug.

Compounds in Melinjo seed perform contacts with LEU853, LEU857, and LEU862, which these amino acids are the most important residues for hydrophobic interaction. There are several amino acid seed those give similarity with statin drug (Pravastatin) and MAH as the original ligand of HMG-CoA Reductase: LYS691, ASN658, MET657, MET655 with PDB 1DQ8; amino acid LYS691, LEU853, GLU559, LYS735, HIS752, LEU857, ASP690 with PDB 1HW9 (Figure 4, 5 and 6). These results indicate that the interaction of piceid, gnetin $\mathrm{C}$, gnemonol $\mathrm{L}$ with HMG-CoA reductase (PDB ID 1DQ8 and 1HW9) residues might lead another way to develop novel HMG-CoA reductase inhibitor. Further study was needed to evaluate anti-hypercholesterolemia activity of the extract and stilbenoid from the seed of this plant through preclinical and clinical studies. In addition, safety study was needed to guarantee the use of the extract.

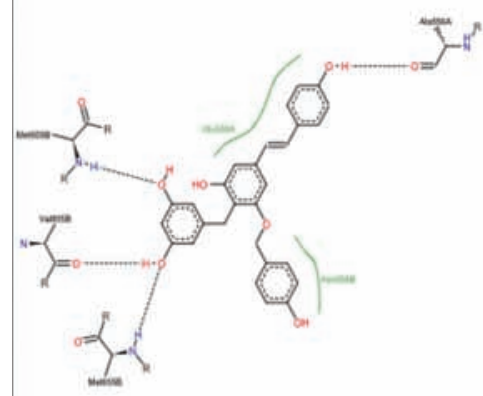

Latifolol_1DQ8

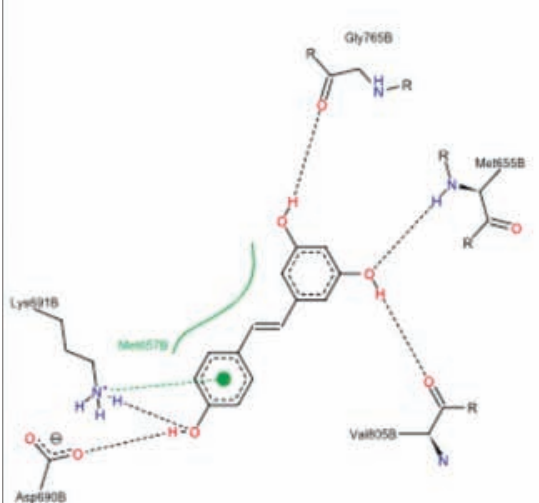

Resveratrol_1DQ8

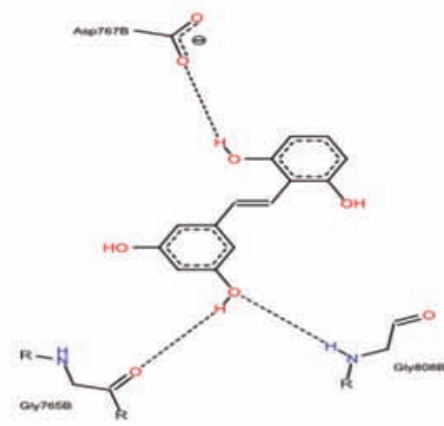

Piceid_1DQ8

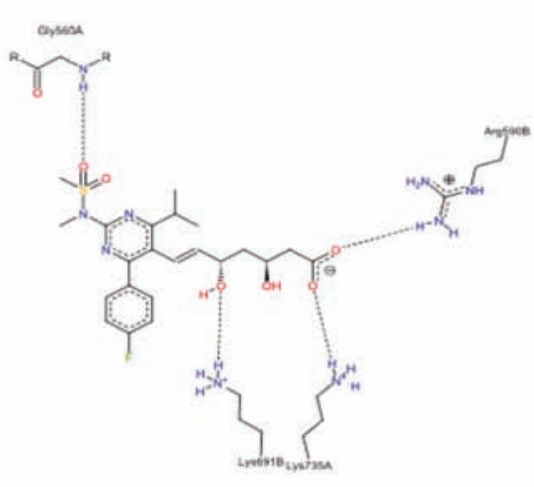

Rosuvastatin_1DQ

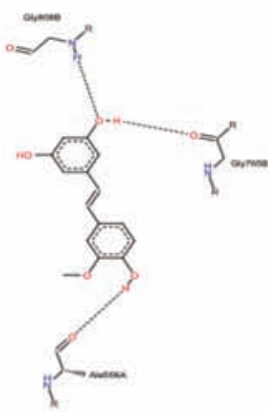

Pravastatin_1DQ8

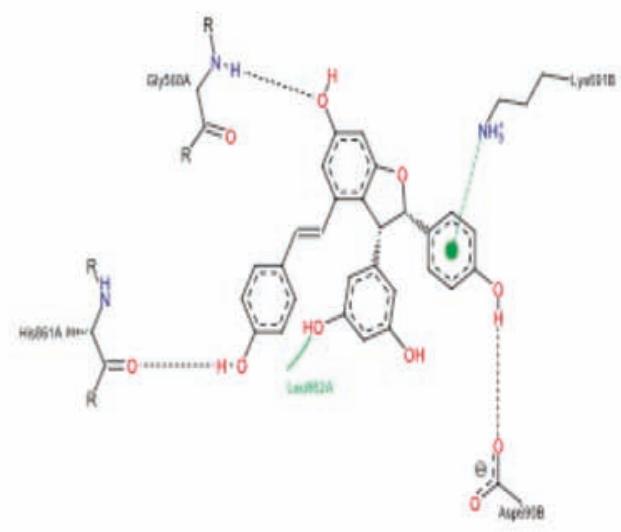

viniferin_1DQ8

Figure 4: Binding mode of compound compounds with HMG CoA reductase [PDB 1dq8] by docking studies using Autodock4, visualization by PoseView 


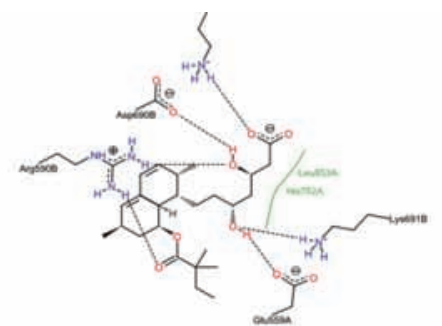

Simvastatin_1HW9

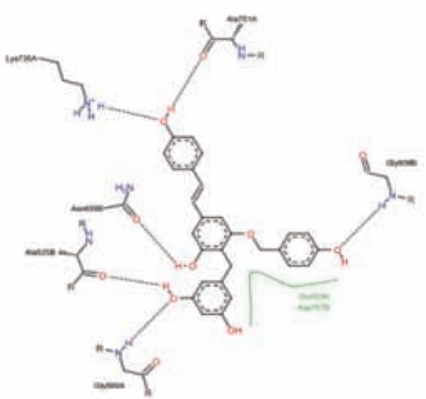

Gnetin C_1HW9

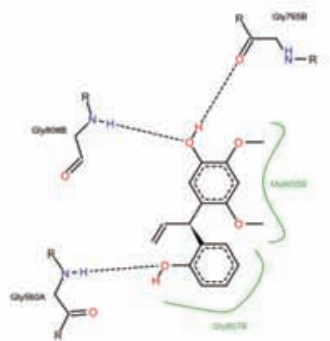

Latifolol_1HW9

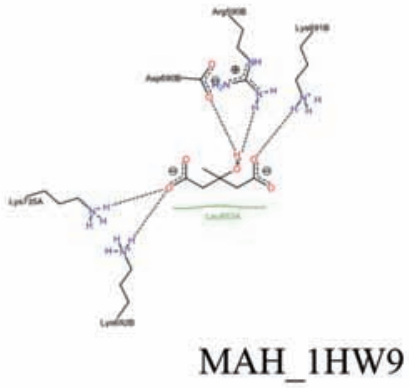

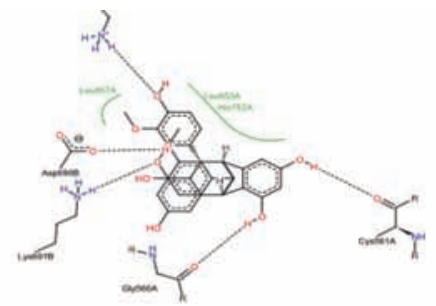

Gnemonol M_1HW9

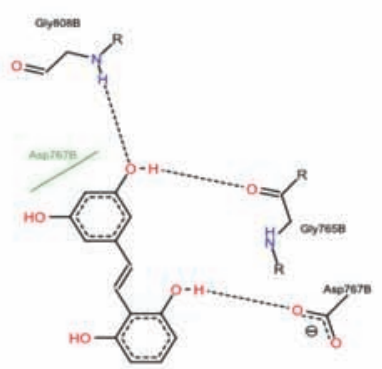

Gnetol_1HW9

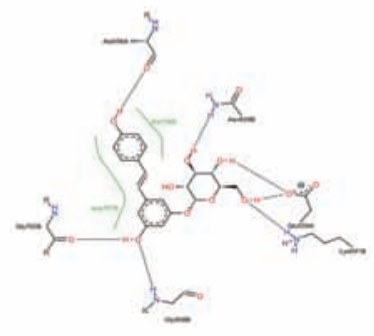

Piceid_1HW9

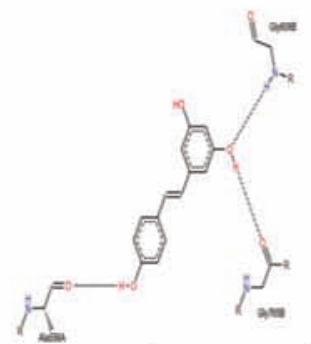

Resveratrol_1HW9

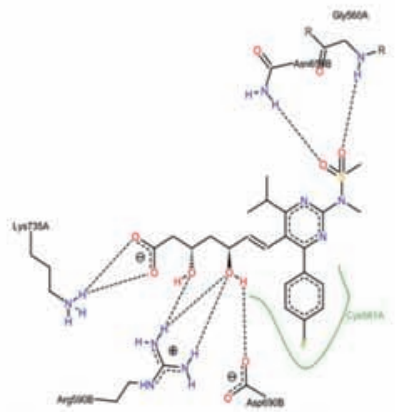

Rosuvastatin_1HW9

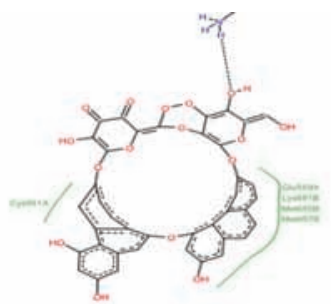

Gnemoside B_1HW9

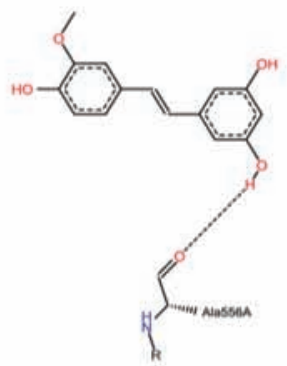

Isorhapontigenin_1HW9

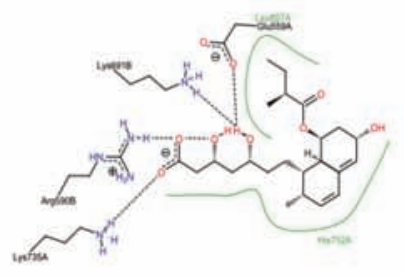

Pravastatin_1HW9

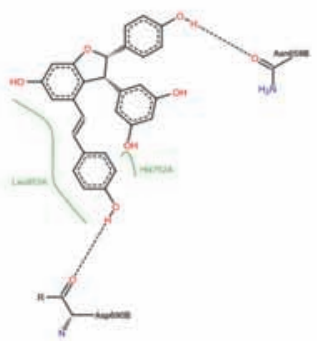

Viniferin_1HW9

Figure 5: Binding mode of comppounds with HMG-CoA reductase [PDB 1hw8] by docking study using Autodock 4, visualization by Pose View 
Table 3: Free binding energy (kcal/mol) of MAH, SIM4 (original ligand) resveratrol and isolated compounds from Melinjo seed

\begin{tabular}{|c|c|c|c|c|c|}
\hline & \multirow[t]{2}{*}{ Compound } & \multirow{2}{*}{$\begin{array}{c}\text { Affinity } \\
\text { (kcal/mol) } \\
\text { PDB: } 1 \mathrm{dq} 8\end{array}$} & \multirow{2}{*}{$\begin{array}{c}\text { Affinity } \\
\text { (kcal/mol) } \\
\text { PDB: 1HW9 }\end{array}$} & \multirow[t]{2}{*}{$\begin{array}{l}\text { Inhibiton constant } \\
\text { (1dq8) }\end{array}$} & \multirow[t]{2}{*}{$\begin{array}{l}\text { Inhibition constant } \\
(1 \mathrm{HW} 9)\end{array}$} \\
\hline & & & & & \\
\hline 1 & trans-resveratrol & -7.38 & -7.35 & $3.92 \mu \mathrm{M}$ & $4.11 \mu \mathrm{M}$ \\
\hline 2 & Piceid & -9.76 & -8.69 & $69.55 \mathrm{nM}$ & $428.71 \mathrm{nM}$ \\
\hline 3 & Gnetin C & -10.31 & -9.33 & $27.87 \mathrm{nM}$ & $144.31 \mathrm{nM}$ \\
\hline 4 & Gnetol & -7.74 & -5.94 & $2.11 \mu \mathrm{M}$ & $44.05 \mu \mathrm{M}$ \\
\hline 5 & Isorhapontigenin & -7.37 & -7.6 & $3.95 \mu \mathrm{M}$ & $2.68 \mu \mathrm{M}$ \\
\hline 6 & $\varepsilon$-Viniferin & -9.28 & -7.14 & $156.83 \mathrm{nM}$ & $5.87 \mu \mathrm{M}$ \\
\hline 7 & Gnemonol L & -13.52 & -12.2 & 123.pM & $1.15 \mathrm{nM}$ \\
\hline 8 & Gnemonol M & -8.64 & -7.42 & $461.04 \mathrm{nM}$ & $3.62 \mu \mathrm{M}$ \\
\hline 9 & Gnemonoside B & -12.3 & -10.27 & $967.72 \mathrm{pM}$ & $29.89 \mathrm{nM}$ \\
\hline 10 & Latifolol & -7.58 & -4.72 & $2.77 \mu \mathrm{M}$ & $349.39 \mu \mathrm{M}$ \\
\hline 11 & Pravastatin & -7.83 & -9.28 & $157.9 \mathrm{nM}$ & $1.81 \mu \mathrm{M}$ \\
\hline 12 & Rosuvastatin & -9.76 & -9.26 & $70.26 \mathrm{nM}$ & $163.2 \mathrm{nM}$ \\
\hline 13 & MAH & -6.51 & -6.55 & $16.96 \mu \mathrm{M}$ & $15.77 \mu \mathrm{M}$ \\
\hline
\end{tabular}
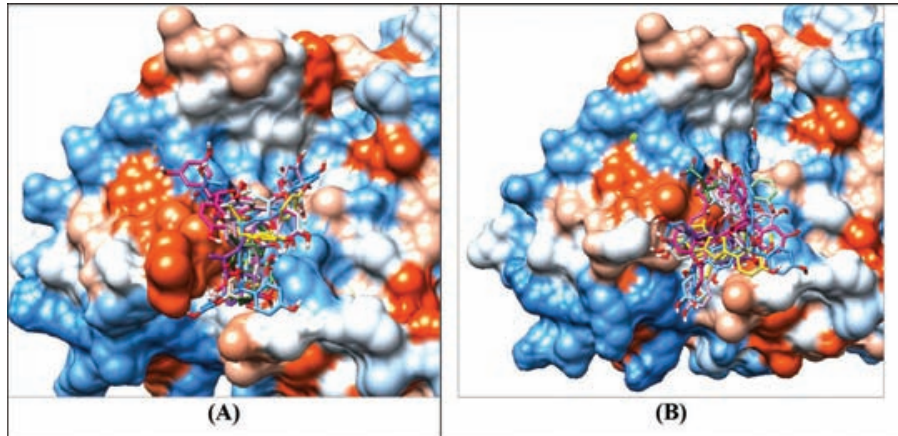

Figure 6: The molecular surface of the binding pocket is coloring and displayed according to hydrophobicity (blue $=$ hydrophilic, orange $=$ hydrophobic), Docking poses of all inhibitors 1-12 obtained for 1DQ8 (A) and 1HW9 (B)

\section{CONCLUSION}

Based on the results of the study, it was concluded that melinjo seed dichloromethane extract not only able to hinder the enzymatic activity of HMG-CoA reductase, but also is potentially prohibit with $\mathrm{MAH}$ substrate against HMG-CoA Reductase receptor, which might suggest its role in treatment of hypercholesterolemia.

\section{ACKNOWLEDGEMENT}

This study was funded by Grant of PITTA 2016 provided by the Directorate of Research and Community Enggagement, Universities Indonesia.

\section{CONFLICT OF INTEREST}

There is no conflict of interest.

\section{ABBREVIATION USED}

HMG-CoA: 3-hydroxy-3-methyl-glutaryl-coenzyme A; MSE: Melinjo seed extract; UPLC-MS: Ultra-high pressure liquid chromatographyMS-MS.

\section{REFERENCES}

1. Barua CC, Haloi P, Barua IC. Gnetum gnemon Linn. : A comprehensive review on its biological, and pharmacognostical potentials. Int J Pharmacogn Phytochem Res. 2015;7(3):531-9.

2. Bhat R, binti Yahya N. Evaluating belinjau (Gnetum gnemon L.) seed flour quality as a base for development of novel food products and food formulations. Food Chem. 2014;156:42-9.

3. Kato E, Tokunaga $Y$, Sakan F. Stilbenoids isolated from the seeds of melinjo (Gnetum gnemon L.) and their biological activity. J Agric Food Chem. 2009;57(6):2544-9

4. Ikuta T, Saito S, Tani H, Tatefuji T, Hashimoto K. Resveratrol derivative-rich melinjo (Gnetum gnemon L.) seed extract improves obesity and survival of C57BL/6 mice fed a high-fat diet. Biosci Biotechnol Biochem. 2015;79(12):2044-9.

5. Narayanan NK, Kunimasa K, YamoriY, Mori M, Mori H, Nakamura K, et al. Antitumor activity of melinjo (Gnetum gnemon L.) seed extract in human and murine tumor models in vitro and in a colon-26 tumor-bearing mouse model in vivo. Cancer Med. 2015;4(11):1767-80.

6. Konno H, Kanai Y, Katagiri M, Watanabe T, Mori A, Ikuta T, et al. Melinjo (Gnetum gnemon L.) Seed Extract Decreases Serum Uric Acid Levels in Nonobese Japanese Males: A Randomized Controlled Study. Evid Based Complement Alternat Med. 2013:589169

7. Mun'im A, Munadhil MA, Puspitasari N, Yanuar A. Angiotensin converting enzyme inhibitory activity of melinjo (Gnetum gnemon) seed and molecular docking of its stilbene constituents. Asian J Pharm Clin Res. 2017;10(3):1-6.

8. Iliya I, Ali Z, Tanaka T, linuma M, Furusawa M, Nakaya K ichi, et al. Stilbene derivatives from Gnetum gnemon Linn. Phytochemistry 2003;62(4):601-6.

9. Kolouchová-Hanzlíková I, Melzoch K, Filip V, Šmidrkal J. Rapid method for resveratrol determination by HPLC with electrochemical and UV detections in wines. Food Chem. 2004;87(1):151-8.

10. Burns J, Yokota T, Ashihara H, Lean M, Crozier A. Plant foods and herbal sources of resveratrol. J Agric Food Chem. 2002;50(11):3337-40.

11. Opie LH, Lecour S. The red wine hypothesis: from concepts to protective signalling molecules. Eur Heart J. 2007;28(14):1683-93.

12. Cho IJ, Ahn JY, Kim S, Choi MS, Ha TY. Resveratrol attenuates the expression of HMG-CoA reductase mRNA in hamsters. Biochem Biophys Res Commun. 2008;367(1):190-4.

13. Mundra S, Mahesh R. 2- (phenylamino) ethanone derivatives as Falcipain-2 inhibitors. J Young Pharm. 2015;7(2):96-105

14. Islam R, Zaman A, Jahan I, Chakravorty R. In silico QSAR analysis of quercetin reveals its potential as therapeutic drug for Alzheimer' $s$ disease. J Young Pharm. 2013;5(4):173-9

15. Zhou Y, WuWH, Zhao QB, Wang XY, Bao B. Inhibition of HMG-CoA reductase by MFS, a purified extract from the fermentation of marine fungus Fusarium solan FG319, and optimization of MFS production using response surface methodology. Chin J Nat Med. 2015;13(5):346-54.

16. Istvan ES, Palnitkar M, Buchanan SK DJ. Crystal structure of the catalytic portion of human HMG-CoA reductase: insights into regulation of activity and catalysis. 
EMBO J. 2000;19(5):819-30

17. ES I, J D. Structural mechanism for statin inhibition of HMG-CoA reductase. Science. 2001;292(5519):1160-4

18. Morris GM, Huey R, Lindstrom W, Sanner MF, Belew RK, Goodsell DS OA. AutoDock4 and AutoDockTools4: Automated docking with selective receptor flexibility. J Comput Chem. 2009;30(16):2785-91.

19. Wolber G, Dornhofer AA, Langer T. Efficient overlay of small organic molecules using 3D pharmacophores. J Comput Aided Mol Des. 2006;20:773-88.

20. Su P, Doerksen RJ, Chen S, Sung W, Juan C, Rawendra RDS, et al. Screening and profiling stilbene-type natural products with angiotensin-converting enzyme inhibitory activity from Ampelopsis brevipedunculata var. hancei (Planch.) Rehder. J Pharm Biomed Anal. 2015:108:70-7.

21. Iqbal D, Khan MS, Khan A, Khan MS, Ahmad S, Srivastava AK BP. In vitro screen- ing for $\beta$-hydroxy- $\beta$-methylglutaryl-CoA reductase inhibitory and antioxidant activity of sequentially extracted fractions of Ficus palmata Forsk. Biomed Res Int. 2014;762620.

22. Perchellet JP, Perchellet EM, Crow KR, Buszek KR, Brown N, Ellappan S, Gao G, Luo D, Minatoya M LG. Novel synthetic inhibitors of 3-hydroxy-3-methylglutaryl-coenzyme A (HMG-CoA) reductase activity that inhibit tumor cell proliferation and are structurally unrelated to existing statins. Interntional J Mol Med. 2009;24(5):633-43.

23. McKenney JM. Pharmacologic Characteristics of Statins. Clin Cardiol. 2003;26:32-8

24. Kolouchová-Hanzlíková I, Melzoch K, Filip V, Šmidrkal J. Rapid method for resveratrol determination by HPLC with electrochemical and UV detections in wines. Food Chem. 2004;87(1):151-8.

Article History: Submission Date : 18-06-2017 ; Revised Date : 31-07-2017; Acceptance Date : 27-08-2017.

Cite this article: Hafidz KA, Azminah, Yanuar A, Artha Y, Mun'im A. HMG-CoA Reductase Inhibitory Activity of Gnetum gnemon Seed Extract and Identification of Potential Inhibitors for Lowering Cholesterol Level. J Young Pharm. 2017;9(4):559-65. 